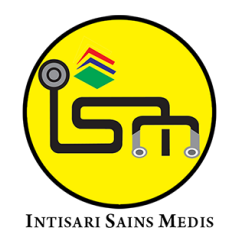

Published by Intisari Sains Medis

\section{Efek pemberian propolis pada fungsi ginjal dan hepar tikus putih (Rattus Norvegicus) yang diinduksi cisplatin}

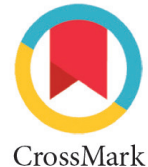

CrossMark

\author{
Novriantika Lestari ${ }^{1 *}$, Fajrianti Haniyah² ${ }^{2}$ Annisa Puspa Sari², Liya Agustin Umar ${ }^{3}$, Elvira Yunita ${ }^{4}$
}

'Departemen Farmakologi, Fakultas Kedokteran dan IImu Kesehatan, Universitas Bengkulu, Bengkulu, Indonesia;

2Program Studi Kedokteran, Fakultas Kedokteran dan Ilmu Kesehatan, Universitas Bengkulu, Bengkulu, Indonesia;

${ }^{3}$ Departemen Biologi, Fakultas Kedokteran dan IImu Kesehatan, Universitas Bengkulu, Bengkulu, Indonesia;

${ }^{4}$ Departemen Biokimia, Fakultas Kedokteran dan IImu Kesehatan, Universitas Bengkulu, Bengkulu, Indonesia;

\section{*Korespondensi:}

Novriantika Lestari;

Departemen Farmakologi, Fakultas Kedokteran dan IImu Kesehatan, Universitas Bengkulu, Bengkulu, Indonesia;

novriantika.lestari@gmail.com

Diterima: 03-04-2021

Disetujui: 20-07-2021

Diterbitkan: 30-07-2021

\title{
ABSTRACT
}

Background: Cisplatin as an anticancer drug results in nephrotoxicity and hepatotoxicity. Accumulation of cisplatin in the body will produce reactive compounds in the form of free radicals which induce oxidative stress that affects kidney and liver functions. Propolis contains flavonoids, phenolic acid, and Caffeic Acid Phenethyl Ester (CAPE) which have the ability to prevent free radical formation and improve kidney and liver function. This study aims to determine the effect of propolis administration to ameliorate of BUN, creatinine, ALT and AST levels in cisplatin-induced rats (Rattus norvegicus).

Methods: The experimental study was conducted with the pre-post-test with control group design approach. The research sample used 30 white rats which were divided into normal (aquadest), Cisplatin (5mg/kg i.p),

and cisplatin+propolis groups. Propolis was given at a dose of $50 \mathrm{mg} / \mathrm{kg}, 100 \mathrm{mg} / \mathrm{kg}$ and $200 \mathrm{mg} / \mathrm{kg}$ orally for seven days, four days after cisplatin induction. Rat blood was taken for analysis of Bloof Urea Nitrogen (BUN), Creatinine, ALT, and AST levels. Data were analyzed using SPSS version 26 for Windows.

Results: The results showed that there were significant differences in levels of BUN, Creatinine, ALT and AST between groups $(p<0.05)$. Propolis treatment at doses of $50 \mathrm{mg} / \mathrm{kg}, 100 \mathrm{mg} / \mathrm{kg}$ and $200 \mathrm{mg} / \mathrm{kg}$ can reduce levels of BUN/urea, creatinine, ALT, and AST in rats that have been induced by cisplatin significantly $(p<0,05)$.

Conclusion: Propolis has a therapeutic effect on cisplatin drug-induced nephrotoxicity and hepatotoxicity by affecting the BUN, creatinine, ALT, and AST levels in rats.

Keywords: Propolis, Cisplatin, BUN, Creatinine, ALT, AST.

Cite This Article: Lestari, N., Haniyah, F., Sari, A.P., Umar, L.A., Yunita, E. 2021. Efek pemberian propolis pada fungsi ginjal dan hepar tikus putih (Rattus Norvegicus) yang diinduksi cisplatin. Intisari Sains Medis 12(2): 508-512. D0l: 10.15562/ism.v12i2.1017

\section{ABSTRAK}

Latar Belakang: Penggunaan cisplatin sebagai obat antikanker menghasilkan efek nefrotoksisitas dan hepatotoksisitas imbas obat. Akumulasi cisplatin di dalam tubuh akan menghasilkan senyawa reaktif berupa radikal bebas yang menginduksi terjadinya stress oksidatif sehingga akan berpengaruh ke fungsi ginjal dan hepar. Propolis mengandung flavonoid, asam fenolat, dan Caffeic Acid Phenethyl Ester (CAPE) yang memiliki kemampuan mencegah pembentukan radikal bebas dan memperbaiki fungsi ginjal dan hepar. Penelitian ini bertujuan untuk mengetahui pengaruh pemberian propolis terhadap pemulihan kadar ureum, kreatinin, ALT dan AST darah pada tikus putih (Rattus norvegicus) yang telah diinduksi cisplatin.

Metode: Penelitian eksperimental ini dilakukan dengan pendekatan pre-post-test with control group design. Sampel penelitian menggunakan 30 ekor tikus puth yang dibagi menjadi kelompok normal (aquadest), Cisplatin (5mg/kgbb i.p) dan kelompok cisplatin+propolis. Propolis diberikan dengan dosis $50 \mathrm{mg} / \mathrm{kgbb}, 100 \mathrm{mg} / \mathrm{kgbb}$ dan $200 \mathrm{mg} / \mathrm{kgbb}$ secara oral selama tujuh hari, empat hari setelah induksi cisplatin. Darah tikus diambil untuk analisis kadar Blood Urea Nitrogen (BUN), Kreatinin, ALT, dan AST. Data dianalisis dengan SPSS versi 26 untuk Windows.

Hasil: Hasil penelitian menunjukkan terdapat perbedaan kadar BUN, Kreatinin, ALT, dan AST yang bermakna antar kelompok $(p<0,05)$. Pemberian propolis dengan dosis $50 \mathrm{mg} / \mathrm{kgBB}, 100 \mathrm{mg} / \mathrm{kgBB}$ dan $200 \mathrm{mg} / \mathrm{kgBB}$ dapat menurunkan kadar BUN/ureum, kreatinin, ALT, dan AST pada tikus yang telah diinduksi cisplatin secara bermakna $(p<0,05)$.

Kesimpulan: Propolis memiliki efek terapi pada nefrotoksisitas dan hepatotoksisitas akibat obat 
cisplatin dengan mempengaruhi kadar BUN/ureum, kreatinin, ALT, dan AST pada tikus.

Kata kunci: ALT, AST, Cisplatin, Kreatinin, Propolis, Ureum.

Sitasi Artikel ini: Lestari, N., Haniyah, F., Sari, A.P., Umar, L.A., Yunita, E. 2021. Efek pemberian propolis pada fungsi ginjal dan hepar tikus putih (Rattus Norvegicus) yang diinduksi cisplatin. Intisari Sains Medis 12(2): 508-512. D0I: 10.15562/ism.v12i2.1017

\section{PENDAHULUAN}

Cisplatin pertama kali dikenal pada tahun 1845 sebagai senyawa yang mengandung platinum. Saat ini cisplatin digunakan sebagai salah satu obat antikanker yang efektif dan telah digunakan selama beberapa dekade. ${ }^{1}$ Cisplatin dikenal juga dengan nama cisplatinum atau cisdiamminedichloroplatinum(II) merupakan salah satu obat yang digunakan sebagai kemoterapi dalam pengobatan kanker seperti kanker testis, ovarium, serviks, kepala, leher, dan kanker paru-paru. ${ }^{2}$

Toksisitas imbas obat cisplatin menyebabkan penipisan dan inaktivasi glutation dan antioksidan yang dapat menyebabkan akumulasi Reactive Oxygen Species (ROS) endogen dan stres oksidatif. Induksi hewan coba dengan cisplatin merupakan metode baku untuk pembuatan hewan coba dengan nefrotoksisitas. ${ }^{3}$ Di sisi lain, cisplatin juga merusak arsitektur lobulus hepar dan meningkatkan ukuran sinusoidal hepar. ${ }^{4}$ Cisplatin dapat menyebabkan kerusakan oksidatif pada hepar, salah satunya cedera yang dapat dihasilkan adalah mengganggu fungsi dan struktur pada mitokondria. ${ }^{5}$ Insidensi hepatotoksik dari cisplatin belum diketahui dengan pasti dibandingkan insidensi nefrotoksik cisplatin. ${ }^{4}$ Akan tetapi studi terdahulu mendapatkan angka insiden nefrotoksisitas akibat obat pada pasien dengan terapi cisplatin adalah sebesar $14-100 \%{ }^{6}$

Propolis adalah produk yang dihasilkan dari sekresi kelenjar mandibula dan hipofaring lebah. Propolis memiliki lebih dari 300 komponen senyawa yang memiliki efek antioksidan tinggi. ${ }^{7}$ Propolis sebagai antioksidan dapat menangkap radikal hidroksil dan superoksida kemudian menetralkan radikal bebas sehingga melindungi sel dan mempertahankan keutuhan struktur sel dan jaringan serta dapat melindungi membran lipid terhadap reaksi oksidan yang bersifat merusak. ${ }^{8}$ Propolis telah diketahui dapat memperbaiki gambaran histopatologi ginjal tikus model diabetes melitus tipe $1 .{ }^{9}$ Pemberian ekstrak etanol propolis juga mampu memperbaiki kerusakan hepar yang telah terpapar $\mathrm{CCl}_{4}$ dengan cara menurunkan transaminase serum dan peroksidasi lipid hepar dimana bertujuan untuk meningkatkan glutation hepar. ${ }^{10}$

Berdasarkan pada pemaparan di atas maka penelitian ini bertujuan untuk mengetahui pengaruh pemberian propolis terhadap fungsi ginjal dan hepar tikus yang diinduksi cisplatin melalui parameter kadar Blood Urea Nitrogen (BUN)/ureum, kreatinin, Alanine Aminotransferase (ALT) dan Aspartate Aminotransferase (AST) darah.

\section{METODE}

Penelitian eksperimental ini dilakukan dengan pendekatan pre-post-test without control group design. Hewan coba yang digunakan adalah tikus jenis Rattus

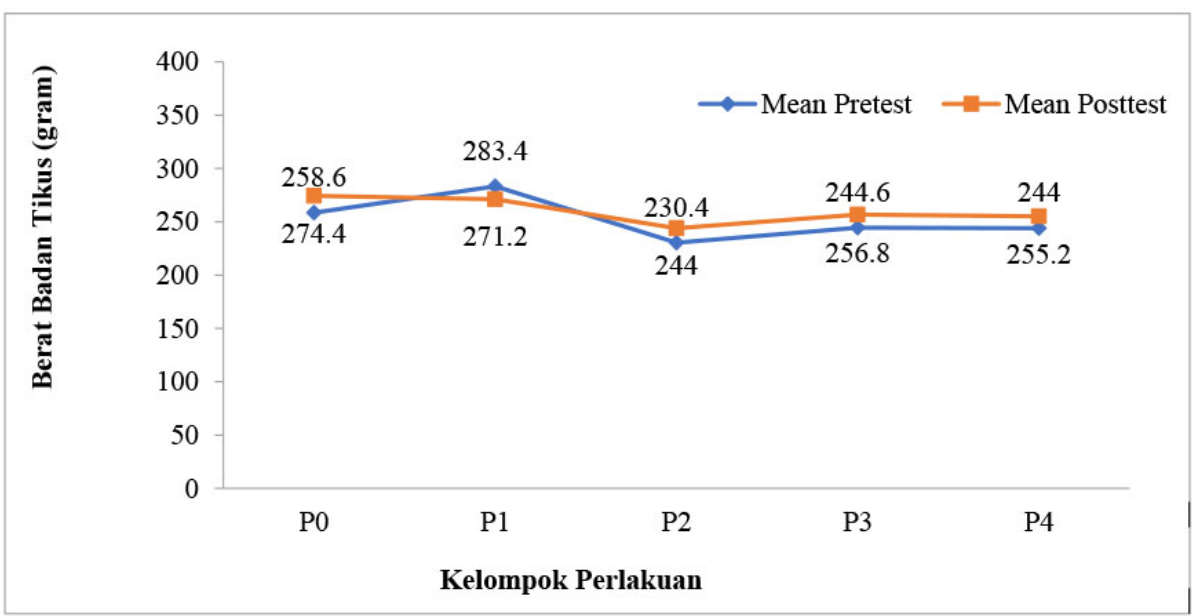

Gambar 1. Perubahan berat badan tikus. (P0) Kelompok kontrol; (P1) Kelompok yang diberikan Cisplatin $5 \mathrm{mg} / \mathrm{kgBB}$; (P2) kelompok yang diberikan Cisplatin $5 \mathrm{mg} / \mathrm{kgBB}$ dan Propolis $50 \mathrm{mg} / \mathrm{kgBB}$; (P3) Kelompok yang diberikan Cisplatin 5 mg/kgBB dan Propolis 100 mg/kgBB; dan (P4) Kelompok yang diberikan Cisplatin $5 \mathrm{mg} / \mathrm{kgBB}$ dan Propolis $200 \mathrm{mg} / \mathrm{gBB}$. 


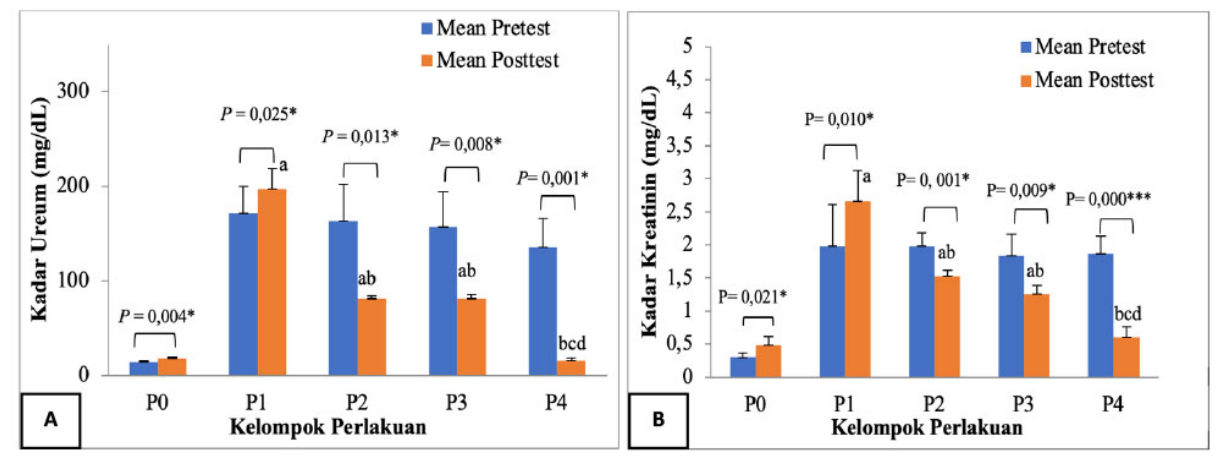

Gambar 2. Perubahan kadar BUN/Ureum (A) dan Kreatinin (B) (P adalah nilai bermaknasi pretest dan posttest; ${ }^{*}$ : $\mathrm{P}<0,05 ;{ }^{* *}: \mathrm{P}<0,01 ;{ }^{* * *}: \mathrm{P}<0,001 ; \mathrm{P} 0$ : Kelompok kontrol; P1: Kelompok yang diberikan Cisplatin 5 mg/kgBB; P2: kelompok yang diberikan Cisplatin $5 \mathrm{mg} / \mathrm{kgBB}$ dan Propolis $50 \mathrm{mg} / \mathrm{kgBB}$; P3: kelompok yang diberikan Cisplatin $5 \mathrm{mg} / \mathrm{kgBB}$ dan Propolis $100 \mathrm{mg} /$ kgBB; dan P4: Kelompok yang diberikan Cisplatin $5 \mathrm{mg} / \mathrm{kgBB}$ dan Propolis $200 \mathrm{mg} / \mathrm{gBB})$.
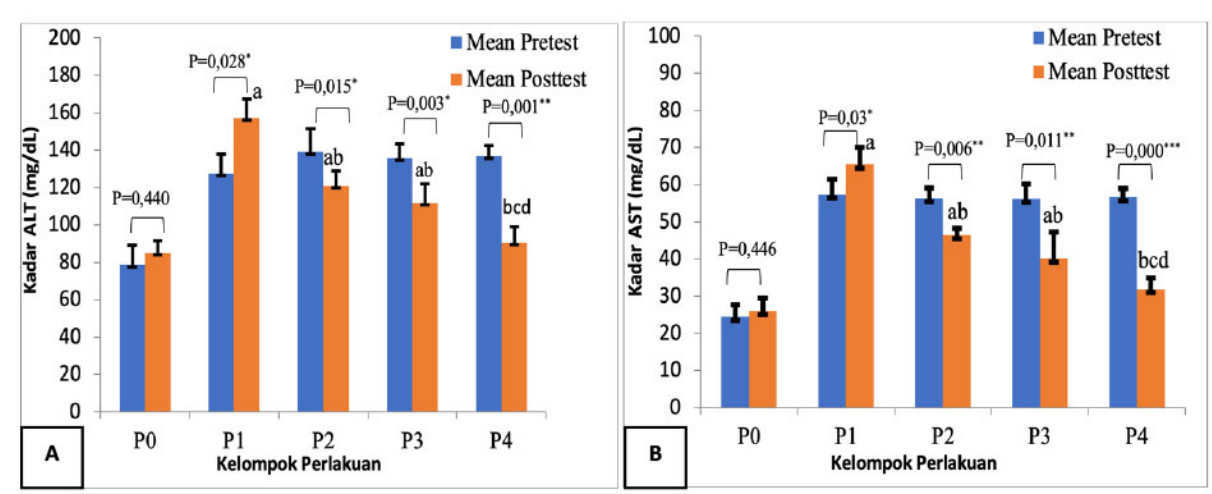

Gambar 3. Perubahan kadar Alanine Aminotransaminase (ALT) (A) dan Aspartate Aminotransferase (AST) (B) tikus ( $\mathrm{P}$ adalah nilai bermaknasi pretest dan posttest; ${ }^{*}: \mathrm{P}<0,05 ;{ }^{* *}: \mathrm{P}<0,01 ;{ }^{* *}: \mathrm{P}<0,001$; $\mathrm{P} 0$ : Kelompok kontrol; P1: Kelompok yang diberikan Cisplatin $5 \mathrm{mg} / \mathrm{kgBB}$; P2: kelompok yang diberikan Cisplatin $5 \mathrm{mg} / \mathrm{kgBB}$ dan Propolis $50 \mathrm{mg} / \mathrm{kgBB}$; P3: kelompok yang diberikan Cisplatin $5 \mathrm{mg} / \mathrm{kgBB}$ dan Propolis $100 \mathrm{mg} / \mathrm{kgBB}$; dan P4: Kelompok yang diberikan Cisplatin 5 mg/kgBB dan Propolis 200 mg/gBB).

melalui sinus orbitalis sebanyak 2 cc untuk mengukur kadar ureum, kreatinin, ALT, dan AST pretest. Selanjutnya dilakukan pemberian propolis selama 7 hari sesuai dengan pedoman studi sebelumnya. ${ }^{13-15}$ Pada hari ke-12 dilakukan pengambilan darah secara intrakardia untuk mengukur kadar ureum, kreatinin, ALT, dan AST post-test. Seluruh data dianalisis menggunakan analisis one-way ANOVA dan dilanjutkan uji post-hoc Tukey dengan nilai kebermaknaan sebesar $\mathrm{p}<0,05$ melalui piranti lunak Statistical Program for Social Science (SPSS) versi 26 untuk Windows.

\section{HASIL}

Pada penelitian ini didapatkan bahwa terdapat perbedaan yang bermakna antara berat badan sebelum dan setelah perlakuan $(\mathrm{p}<0,05)$ baik pada kelompok P0 (274,4 gram vs. 258,6 gram), P1 (283,4 gram vs. 271,2 gram), P2 (244,0 gram vs. 230,4 gram), P3 (256,8 gram vs. 244,6 gram), dan P4 (255,2 gram dan 244,0 gram) (Gambar 1). Namun, tidak terdapat perbedaan bermakna antara kelompok perlakuan P0-P4 ( $\mathrm{p}>0,05)$.

Induksi cisplatin meningkatkan kadar ureum dan kreatinin pretest yang bermakna pada kelompok P1-P4 dibandingkan kelompok kontrol $(\mathrm{p}<0,05) \quad$ (Gambar 2). Pemberian propolis menurunkan kadar BUN/ureum dan kreatinin posttest yang berbeda bermakna dibandingkan pengukuran pretest $(\mathrm{p}<0,05)$. Di samping itu, terdapat perbedaan yang bermakna pada kadar BUN/ureum dan kreatinin posttest antar kelompok perlakuan $(\mathrm{p}<0,05)($ Gambar 2).

Induksi cisplatin meningkatkan kadar ALT dan AST pretest yang bermakna pada kelompok P1-P4 dibandingkan kelompok kontrol $(\mathrm{p}<0,05)$ (Gambar 3). Pemberian propolis juga menurunkan kadar ALT dan AST posttest yang berbeda bermakna dibandingkan pengukuran pretest $(\mathrm{p}<0,05)$. Disamping itu juga terdapat perbedaan yang bermakna kadar ALT dan AST posttest antar kelompok perlakuan $(\mathrm{p}<0,05)($ Gambar 3).

\section{PEMBAHASAN}

Kadar ureum dan kreatinin tikus yang diinduksi cisplatin mengalami peningkatan setelah perlakuan. Induksi cisplatin memberikan efek toksik pada organ ginjal melalui mekanisme masuknya zat toksik yang dibawa oleh darah yang masuk ke dalam glomerulus ginjal. ${ }^{13,14}$ Zat tersebut menyebabkan nekrosis pada tubulus kontortus proksimal ginjal dan lengkung Henle serta kerusakan sel epitel yang berada di lapisan glomerulus, sehingga terjadi penurunan laju filtrasi glomerulus. ${ }^{14}$

Hal ini semakin didukung dengan pernyataan Perse $M$ dan Veceric-Haler $\mathrm{Z}$ yang menyatakan bahwa pemberian cisplatin dengan dosis yang sama selama 4 hari menyebabkan nefrotoksisitas imbas obat yang ditandai dengan peningkatan kadar ureum dan kreatinin darah. ${ }^{15}$ Efek sistemik paling serius akibat adanya paparan senyawa toksik, seperti cisplatin menyebabkan nefrotoksisitas yang menyerang sel-sel tubulus proksimal. Nekrosis tubulus ginjal yang terjadi dapat menimbulkan penurunan fungsi ginjal yang pada akhirnya dapat memicu terjadinya gagal ginjal akut. ${ }^{3}$ Nefrotoksisitas imbas obat ditegakkan apabila terjadi peningkatan kadar ureum dan kreatinin yang bermakna dari nilai normal selama minimal 24-48 jam terpapar obat. ${ }^{16}$

Kadar ureum dan kreatinin saat ini 
masih menjadi salah satu indikator untuk mengetahui fungsi ginjal. Ureum dibentuk di dalam hati, merupakan suatu produk akhir yang berasal dari katabolisme asamasam amino dan merupakan produk ekskresi metabolisme yang utama. ${ }^{17}$ Kreatinin merupakan suatu produk akhir metabolisme otot yang diproduksi dengan kecepatan yang relatif konstan. ${ }^{18}$

Toksisitas imbas obat akibat cisplatin juga menyebabkan terjadinya penurunan fungsi hepar. Cisplatin menyebabkan penipisan dan inaktivasi glutation dan antioksidan yang dapat menyebabkan akumulasi Reactive Oxygen Species (ROS) endogen dan stres oksidatif. Efek ini tidak hanya terjadi pada organ ginjal, namun juga ke hepar. ${ }^{19}$ Stress oksidatif menyebabkan peningkatan pelepasan sitokin pro inflamasi seperti tumor nekrosis faktor alfa (TNF- $\alpha$ ) dan interleukin-6 (IL-6). Sitokin ini mempercepat proses apoptosis dan kerusakan hepatoseluler. ${ }^{19}$ Di sisi lain, cisplatin juga merusak arsitektur lobulus hepar dan meningkatkan ukuran sinusoidal hepar. ${ }^{4}$ Cisplatin dapat menyebabkan cedera fungsional hepar dimana adanya kerusakan hepar ini dapat dinilai dari peningkatan kadar enzim transaminase yaitu Alanin Aminotransferase (ALT) dan Aspartat Aminotransferase (AST). ${ }^{20.21}$

ALT merupakan enzim sitosol dan terlibat dalam glukoneogenesis. Peningkatan kadar ALT dalam darah terutama disebebkan oleh kerusakan sel hati dan sel otot rangka. Enzim ALT lebih sensitif dibandingkan AST sebagai penanda kerusakan sel rangka, otak, ginjal dan lebih banyak terdapat di jantung. ${ }^{20.21}$ AST merupakan enzim yang terlibat dalam glukoneogenesis, terdapat di dalam sitosol serta mitokondria sel hati, otot rangka, otot jantung, dan eritrosit. Peningkatan kadar AST dalam darah disebebkan oleh kerusakan sel hati yang parah dan disertai nekrosis sehingga enzim dari mitokondria juga ikut keluar sel. ${ }^{20.21}$

Pada penelitian ini pemberian propolis memulihkan kadar ureum, kreatinin, ALT, dan AST yang sebelumnya mengalami peningkatan akibat paparan cisplatin. Penurunan kadar terjadi secara bermakna antara sebelum pemberian propolis dan setelah pemberian. Penurunan tersebut juga seiring dengan peningkatan dosis propolis.

Propolis mengandung senyawa alami yang terbukti memiliki sifat sebagai antioksidan. Komponen propolis yang memiliki aktivitas antioksidan yang kuat dapat ditemukan pada asam fenolat, flavonoid dan Caffeic Acid Phenethyl Ester (CAPE). ${ }^{22,23}$ Asam fenolat dalam propolis bekerja dengan memutus ikatan $\mathrm{O}-\mathrm{H}$ melalui Hydrogen Atom Transfer (HAT) untuk radikal superoksida dan asam monohidroksi sebagai scavengers radikal hidroksi. ${ }^{7}$ Kandungan flavonoid di dalamnya memiliki sifat antioksidan yang sangat baik bila dibandingkan dengan senyawa antioksidan lainnya. ${ }^{22}$ Hasil uji fitokimia yang dilakukan oleh Khairunnisa, Mardawati dan Putri menunjukkan bahwa propolis Trigona $s p$ kaya dengan senyawa flavonoid, fenolik, tanin, saponin, alkaloid, dan terpenoid. ${ }^{24}$

Menurut penelitian yang dilakukan Kumar S dan Pandey AK didapatkan bahwa mekanisme kerja antioksidan mampu menekan pembentukan radikal bebas dengan menghambat enzim yang terlibat dalam pembentukannya, serta mengurangi pembentukan radikal bebas baru dengan cara memutus rantai reaksi dan mengubahnya menjadi produk yang lebih stabil. ${ }^{22}$ Antioksidan juga berperan dalam memperbaiki kerusakan sel dan jaringan yang disebabkan oleh radikal bebas. ${ }^{22}$

Flavonoid mampu bekerja secara langsung maupun tidak langsung, yaitu dengan cara meningkatkan kemampuan ekspresi antioksidan endogen seperti Superoxide Dismutase (SOD), katalase, glutation peroksidase dan antioksidan endogen lain..$^{25}$

Caffeic acid phenethyl ester (CAPE) merupakan salah satu komponen terbesar di dalam propolis, memiliki efek antioksidan, anti inflamasi, imunomodulator, dan antivirus. Sebagai antioksidan, propolis berfungsi mendetoksifikasi SOD yang superoksida menjadi hidrogen peroksida, kemudian enzim CAT dan glutation peroksidase (GSH-Px) menghasilkan air dengan mengkonversi hidrogen peroksida untuk mencegah terjadinya kerusakan akibat ROS di membran sel. ${ }^{23}$

Hasil penelitian ini sejalan dengan penelitian yang dilakukan Ogeturk $M$ et al., yang menjelaskan bahwa pemberian kandungan CAPE dalam propolis mampu menurunkan kadar ureum darah yang meningkat akibat paparan $\mathrm{CCl}_{4}$, akan tetapi tidak bermakna terhadap penurunan kadar MDA. Pemberian propolis secara utuh lebih baik dalam menurunkan kadar ureum dan kreatinin darah kembali dalam kadar normal dibandingkan dengan pemberian kandungan CAPE saja. ${ }^{26}$

Propolis juga menunjukkan efek hepatoprotektif yang ditunjukkan dengan penurunan kadar AST dan ALT setelah perlakukan pemberian cisplatin. Hal ini sejalan dengan hasil penelitian sebelumnya yang menunjukkan bahwa propolis potensi hepatoprotektif sebagai antioksidan yang baik terhadap induksi furan yang menyebabkan kerusakan hepatoseluler pada tikus. Dimana propolis mengandung lebih dari 150 polifenol senyawa seperti flavonoid dan asam fenolik, termasuk esternya. ${ }^{27}$

Selain itu hasil ini juga sejalan dengan penelitian yang dilakukan Bhadauria yang menjelaskan bahwa pemberian propolis mampu menurunkan kadar ALT dan AST dalam darah yang semula meningkat akibat paparan senyawa toksik. ${ }^{10}$ Hasil penelitian yang dilakukan Talas ZS et al., juga menjelaskan bahwa dengan pemberian dosis propolis $200 \mathrm{mg} / \mathrm{kgBB}$ selama 5 hari menunjukkan hasil yang bermakna menurunkan kadar ALT dan AST pada tikus yang diinduksi L-NAME dengan hasil rata-rata 201,23 IU/L menjadi 130,25 IU/L setelah diberikan propolis. ${ }^{28}$ Penurunan kadar ALT dan AST dalam kelompok propolis+L-NAME itu dikarenakan propolis dapat mencegah L-NAME dalam kerusakan akut pada jaringan dan lipid yang terakumulasi di dalam jantung dan hati. ${ }^{28}$

\section{SIMPULAN}

Berdasarkan hasil penelitian dapat disimpulkan bahwa induksi cisplatin meningkatkan kadar ureum, kreatinin, ALT dan, AST darah secara bermakna, sedangkan pemberian propolis dapat menurunkan kadar ureum, kreatinin, ALT dan, AST darah secara bermakna. Propolis memiliki efek terapi nefrotoksisitas dan hepatotoksisitas imbas obat akibat cisplatin. 


\section{KONFLIK KEPENTINGAN}

Penulis menyatakan bahwa penelitian ini bebas dari berbagai konflik kepentingan.

\section{ETIKA PENELITIAN}

Penelitian ini telah mendapatkan izin dari KomiteEtikPenelitian Fakultas Kedokteran dan Ilmu Kesehatan Universitas Bengkulu (No : 104/UN30.14.9/LT/2020).

\section{PENDANAAN}

Penulis menyatakan penelitian ini tidak mendapatkan bantuan dana dari pemerintah ataupun sektor swasta lainnya.

\section{KONTRIBUSI PENULIS}

Novriantika Lestari berkontribusi dalam konsep penelitian, supervisi penelitian, analisis data dan penulisan naskah publikasi. Fajrianti Haniyah dan Annisa Puspa Sari berkontribusi dalam pengumpulan data, analisis, dan penulisan naskah publikasi. Liya Agustin dan Elvira Yunita berkontribusi dalam supervisi penelitian dan analisis data.

\section{DAFTAR PUSTAKA}

1. Singh TD, Meitei HT, Sharma AL, Robinson A, Singh LS, Singh TR. Anticancer properties and enhancement of therapeutic potential of cisplatin by leaf extract of Zanthoxylum armatum DC. Biol Res. 2015;48(1):46.

2. Dasari S, Tchounwou PB. Cisplatin in cancer therapy: molecular mechanisms of action. Eur J Pharmacol. 2014;740:364-378.

3. Perše M, Večerić-Haler Ž. CisplatinInduced Rodent Model of Kidney Injury: Characteristics and Challenges. Biomed Res Int. 2018;2018:1462802.

4. Mir M, Arab MR, Shahraki MR, Mashhadi MA, Salar MS, Aval FS, et al Toxic Effects of Cisplatin on Hepatocytes and Liver Enzymes of Rats. Anatomical Sciences. 2015;12(4):171-176.

5. Naqshbandi A, Khan MW, Rizwan S, Rehman SU, Khan F. Studies on the protective effect of dietary fish oil on cisplatin induced nephrotoxicity in rats. Food Chem Toxicol. 2012;50(2):265-273.

6. Miller RP, Tadagavadi RK, Ramesh G, Reeves WB. Mechanisms of Cisplatin nephrotoxicity. Toxins (Basel). 2010;2(11):24902518.

7. Kurek-Górecka A, Rzepecka-Stojko A, Górecki M, Stojko J, Sosada M, SwierczekZieba G. Structure and antioxidant activity of polyphenols derived from propolis. Molecules. 2013;19(1):78-101.

8. Bankova VS, de Castro SL, Marcucci MC. Propolis: Recent advances in chemistry and plant origin. Apidologie. 2000;31(1):3-15

9. Higuchi K, Yanagawa T. Evaluating dose of cisplatin responsible for causing nephrotoxicity. PLoS One. 2019;14(4):e0215757.

10. Bhadauria M. Combined treatment of HEDTA and propolis prevents aluminum induced toxicity in rats. Food Chem Toxicol. 2012;50(7):2487-2495.

11. Bentli R, Parlakpinar H, Polat A, Samdanci E, Sarihan ME, Sagir M. Molsidomine prevents cisplatin-induced hepatotoxicity. Arch Med Res. 2013;44(7):521-528.

12. El Menyiy N, Al-Waili N, El Ghouizi A, Al-Waili W, Lyoussi B. Evaluation of antiproteinuric and hepato-renal protective activities of propolis in paracetamol toxicity in rats. Nutr Res Pract. 2018;12(6):535-540.

13. Ibrahim NA. The possible protective effect of bee propolis on experimentally mediated cisplatin reproductive toxicity: a histological and immunohistochemical study. The Egyptian Journal of Histology. 2013;36(1):78-86.

14. Barkin RM. Toxicologic emergencies. Pediatr Ann. 1990;19(11):629-633.

15. Perše M, Večerić-Haler Ž. CisplatinInduced Rodent Model of Kidney Injury: Characteristics and Challenges. Biomed Res Int. 2018;2018:1462802.

16. Sales GTM, Foresto RD. Drug-induced nephrotoxicity. Rev Assoc Med Bras (1992). 2020;66Suppl 1(Suppl 1):s82-s90.

17. Weiner ID, Mitch WE, Sands JM. Urea and Ammonia Metabolism and the Control of Renal Nitrogen Excretion. Clin J Am Soc Nephrol. 2015;10(8):1444-1458.

18. Hediger MA, Smith CP, You G, Lee WS, Kanai Y, Shayakul C. Structure, regulation and physiological roles of urea transporters. Kidney Int. 1996;49(6):1615-1623.
19. Cüre MC, Cüre E, Kalkan Y, et al. Infliximab Modulates Cisplatin-Induced Hepatotoxicity in Rats. Balkan Med J. 2016;33(5):504-511.

20. Goorden SM, Buffart TE, Bakker A, Buijs MM. Liver disorders in adults: ALT and AST. Ned Tijdschr Geneeskd. 2013;157(43):A6443.

21. Gowda S, Desai PB, Hull VV, Math AA, Vernekar SN, Kulkarni SS. A review on laboratory liver function tests. Pan Afr Med J. 2009;3:17.

22. Kumar S, Pandey AK. Chemistry and biological activities of flavonoids: an overview. ScientificWorldJournal. 2013;2013:162750.

23. Altuntaş A, Yılmaz HR, Altuntaş A, Uz E, Demir M, Gökçimen A, et al. Caffeic acid phenethyl ester protects against amphotericin B induced nephrotoxicity in rat model. Biomed Res Int. 2014;2014:702981.

24. Khairunnisa K, Mardawati E, Putri SH. Karakteristik Fitokimia dan Aktivitas Antioksidan Ekstrak Propolis Lebah Trigona Sp. Jurnal Industri Pertanian. 2020;2(1):124129.

25. Vargas F, Romecín P, García-Guillén AI, Wangesteen R, Vargas-Tendero P, Paredes MD, et al. Flavonoids in Kidney Health and Disease. Front Physiol. 2018;9:394.

26. Ogeturk M, Kus I, Colakoglu N, Zararsiz I, Ilhan N, Sarsilmaz M. Caffeic acid phenethyl ester protects kidneys against carbon tetrachloride toxicity in rats. J Ethnopharmacol. 2005;97(2):273-280.

27. Kaya E, Yilmaz S, Ceribasi S. Protective Role of Propolis on Low and High Dose Furan-induced Hepatotoxicity and Oxidative Stress in Rats. J Vet Res. 2019;63(3):423-431.

28. Talas ZS, Gogebakan A, Orun I. Effects of propolis on blood biochemical and hematological parameters in nitric oxide synthase inhibited rats by $\mathrm{N} \omega$-Nitro-L-arginine methyl ester. Pak J Pharm Sci. 2013;26(5):915919.

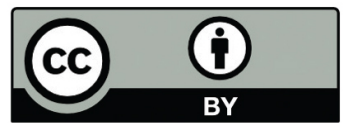

This work is licensed under a Creative Commons Attribution 